tumour line" and line 7 from the bottom "CD8F, breast tumour lines". The same applies to page 90, left-hand column, line 3 . The dosages of LV in this paragraph are in $\mathrm{mg} / \mathrm{m}^{2}$.

The last sentence on page 92 should be: "A dosedependent increase of pyrimidine nucleoside phosphorylase activity was caused by interferon- $\alpha$ [79]; uridine phosphorylase activity also increased after interferon- $\alpha[90] . "$

On page 94 , left-hand column, line 12-13 should have read "... could not be modulated by interferon$\alpha$ [43]." The last sentence of the left-hand column should read "The number of cell lines for which interferon- $\beta$ acts...".

On page 98, line 13-14 from the bottom should read "... allow the cell to grow and divide [110]."

On page 100 the last sentence of the first paragraph should be changed to: "ICI D1694 (Tomudex) has been evaluated in several phase I trials [131]. A preliminary evaluation of phase II trials (in 44 patients) revealed a response rate of $27 \%$ in patients with colorectal cancer [133]." Also on page 100, left-hand column, lines 2-3 from the bottom should have stated that "Both compounds are currently being tested in a clinical trial [136]."

\section{References}

The correct page numbers of references 70 are 35 44.

Reference 133 should be changed to: "Zalcberg I, Cunningham $D$, van Cutsem $E$, et al. Good antitumour activity of the new thymidylate synthase inhibitor tomudex (ZD1694) in colorectal cancer [abstract]. Ann Oncol 1994;5 Suppl 5:133."

\title{
New targets for pyrimidine antimetabolites in the treatment of solid tumours
}

\section{Deoxycytidine kinase}

- Veronique W.T. Ruiz van Haperen and Godefridus J. Peters

Pharm World Sci 1994;16(2):104-12

Tables 1 and 2 contain some wrong figures and references. The relevant parts of these Tables are corrected below. In the caption to Figure 1, ' $x \mathrm{TP}^{\prime}$ should have read NTP. The correct form of reference 57 is: " $X u Y Z$, Plunkett W. Modulation of deoxycytidylate deaminase in intact human leukaemia cells. Action of $2^{\prime}, 2^{\prime}$-difluorodeoxycytidine. Biochem Pharmacol 1992;44:1819-27."

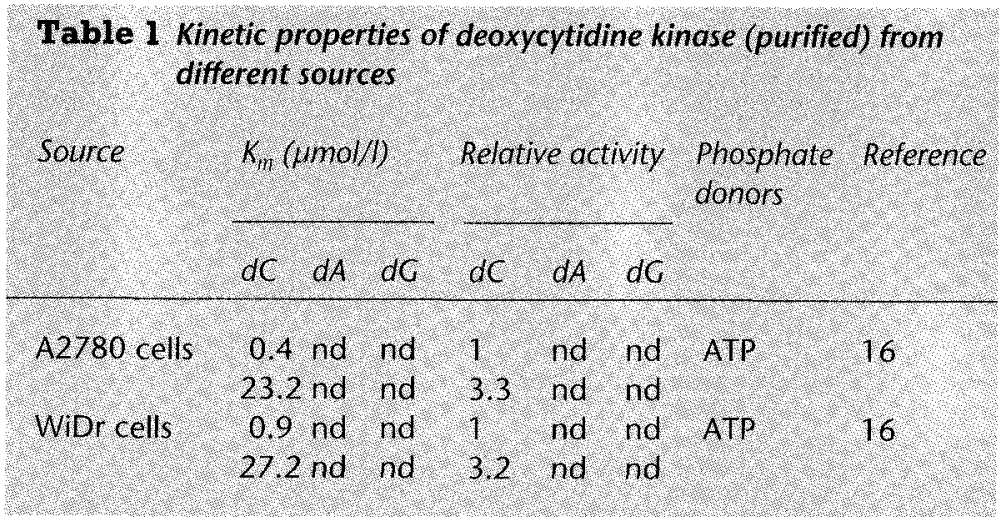

Table 2 Phosphorylation kinetics of deoxycytidine and deoxyadenosine analogues

\begin{tabular}{|c|c|c|c|c|c|c|c|c|c|}
\hline \multirow[t]{2}{*}{ Source } & \multicolumn{4}{|c|}{$K_{m}($ (umolli) } & \multicolumn{4}{|c|}{ Relative activity } & \multirow[t]{2}{*}{ Reference } \\
\hline & dC & Ara-C & $d r d c$ & Anologue & dC & Arace & $d F d C$ & Anclogue & \\
\hline $\begin{array}{l}\text { A2780 cells } \\
\text { WiDr cells }\end{array}$ & $\begin{array}{r}23.2 \\
27.2\end{array}$ & & & & 1 & & $\begin{array}{r}1.4 \\
1.6\end{array}$ & & $\begin{array}{l}16,27 \\
16,27\end{array}$ \\
\hline
\end{tabular}

